\title{
KONTRIBUSI KESEIMBANGAN DAN KELINCAHAN DENGAN KEMAMPUAN MENGGIRING BOLA DALAM PERMAINAN SEPAKBOLA PADA SISWA SMP NEGERI 33 KEPULAUAN SELAYAR
}

\author{
Andi Ridwan $^{1^{*}}$, Hasyim $^{2}$
}

\section{Keywords :}

Keseimbangan;

Kelincahan; Menggiring

Bola.

\section{Corespondensi Author \\ ${ }^{1}$ Universitas Negeri Makassar, ridho.andhy@yahoo.co.id \\ 2 Universitas Negeri Makassar, hasyim@unm.ac.id}

\section{Article History \\ Received: tgl-bln-thn; Reviewed: tgl-bln-thn; Accepted: tgl-bln-thn; Published: tgl-bln-thn}

\begin{abstract}
ABSTRAK
Penelitian ini bertujuan untuk mengetahui kontribusi keseimbangan dan kelincahan dengan kemampuan menggiring bola dalam permainan sepakbola pada siswa SMP Negeri 33 Kepulauan Selayar Desain penelitian atau rancangan penelitian yang digunakan dalam penelitian ini adalah korelasional. Populasi dalam penelitian adalah seluruh siswa SMP Negeri 33 Kepulauan Selayar yang mengikuti kegiatan ekstrakulikuler sepakbola. Sedangkan sampel yang digunakan dalam penelitian ini adalah siswa SMP Negeri 33 Kepulauan Selayar sebanyak 30 siswa dengan tehnik pengambilan sampel adalah porposive sampling. Teknik analisis data yang digunakan adalah analisis regresi tunggal dan ganda yang di analisis dengan menggunakan fasilitas komputer program SPSS versi 21.00 dengan taraf signifikan 95\% atau $\alpha$ 0,05. Berdasarkan analisis data diperoleh hasil: (1) Keseimbangan memiliki kontribusi terhadap kemampuan menggiring bola adalam permainan sepakbola pada siswa SMP Negeri 33 Kepulauan Selayar sebesar 26,4\%, (2) Kelincahan memiliki kontribusi terhadap kemampuan menggiring bola adalam permainan sepakbola pada siswa SMP Negeri 33 Kepulauan Selayar sebesar 62\%, dan (3) Keseimbangan dan kelincahan memiliki kontribusi terhadap kemampuan menggiring bola adalam permainan sepakbola pada siswa SMP Negeri 33 Kepulauan Selayar sebesar $62 \%$.
\end{abstract}

\section{PENDAHULUAN}

Dalam permainan sepakbola terdapat beberapa teknik yang merupakan dasar yang harus dikuasai oleh seorang pemain agar dapat bermain dengan baik guna menuju peningkatan prestasi, seperti menendang bola, menyundul bola, menggiring bola, dan sebagainya. Namun dalam kontribusinya dengan penelitian ini hanya terfokus pada satu teknik saja yakni teknik menggiring bola. Teknik menggiring bola merupakan teknik yang sangat penting dalam permainan sepakbola karena dapat menunjang terciptanya gol dalam suatu pertandingan. Seperti halnya seorang pemain yang sukses menggiring bola dalam usahanya keluar dari kawalan lawan pada saat berada di depan gawang akan memberikan peluang yang besar untuk menciptakan gol karena keberhasilannya menggiring bola dengan melewati lawan yang menghadang menuju ke daerah kosong membuat posisinya bebas dan leluasa dalam melakukan tendangan ke gawang. Untuk mencapai kesuksesan menggiring bola dalam usaha keluar dari kawalan lawan, maka pemain tersebut harus mampu melakukan 


\section{Volume 10 Nomor 2, Juni 2018}

gerakan menggiring bola secara berkelok-kelok atau gerakan merubah arah secara tiba-tiba dengan cepat, karena dengan gerakan-gerakan yang seperti ini akan memudahkan dalam melewati lawan yang menghadang. Perlu diketahui bahwa kemampuan menggiring bola seperti yang diuraikan di atas, tidak dapat terjadi tanpa didukung oleh beberapa unsur yang dapat menunjang, dan salah satunya yang paling dominan adalah unsur kemampuan fisik. Hal ini disebabkan karena tanpa kemampuan fisik yang memadai sulit untuk mengembangkan teknik menggiring yang baik. Begitu pula sebaliknya dengan kemampuan fisik yang baik maka pelaksanaan teknik gerakan menggiring akan dapat ditampilkan secara sempurna.

Komponen fisik yang sangat menunjang dalam melakukan teknik dasar menggiring bola adalah keseimbangan (balance). Adapun yang dimaksud dengan keseimbangan adalah kemampuan seseorang menjaga posisi dan kestabilan badan terutama pada saat melakukan gerakan berubah arah secara cepat. Hal ini penting karena dengan keseimbangan yang baik maka seseorang mampu mengkoordinasikan kecepatan pada saat menggiring bola dalam usaha untuk melewati lawan. Dengan keseimbangan yang sempurna yang dimiliki oleh seorang pemain sepakbola maka dalam melakukan menggirng bola dalam permainan sepakbola akan sempurna. Dengan demikian apabila seorang pemain tidak memiliki keseimbangan yang bagus maka dalam melakukan menggiring bola dalam permainan sepakbola akan lebih sulit dan juga bola yang dibawa akan terasa liar dan lawan akan mudah mencuri bola yang kita bawah. Kemampuan fisik yang dimaksud terutama ditekankan pada unsur kecepatan, dan keseimbangan merupakan hal yang sangat penting agar dapat melakukan gerakan menggiring bola secara berkelok-kelok maupun gerakan mengubah arah secara cepat dalam usaha untuk melewati lawan. Selain keseimbangan, Unsur fisik lain yang menunjang keterampilan menggiring bola adalah kelincahan, karena dalam menggiring bola ada kalanya berhadapan dengan rintangan atau lawan yang berusaha merebut bola, ini berarti sangat dibutuhkan adanya kelincahan atau kemampuan merubah arah atau berhenti secara tiba-tiba untuk merobah posisi tubuh meskipun dalam kecepatan tinggi, maka dalam hal ini kelincahan akan memberikan kemampuan untuk melakukan gerakan-gerakan tersebut. Permasalahan yang timbul bahwa atlet atau pemain pemula seperti siswa SMP Negeri 33 Kepulauan Selayar, tentu belum menguasai teknik dasar menggiring bola secara sempurna. Sedangkan untuk memanfaatkan latihan menggiring bola pada permainan sepakbola yang baik atau secara optimal perlu adanya dukungan atau ditunjang unsur fisik, keseimbangan dan kelincahan.

Menggiring bola merupakan salah satu dari beberapa teknik dasar dalam permainan sepakbola. Menggiring bola atau membawa bola dapat diartikan sebagai mengolah bola dengan menggunakan kaki sambil berlari dengan bola tetap dalam penguasaan. Hal tersebut sejalan dengan apa yang dikemukakan oleh (Ilyas Haddade dan Ismail Tola 1991:50) bahwa: "Dribbling atau menggiring bola adalah membawa bola di dalam kontrol sambil berlari, berarti bola tetap dalam penguasaan (bola selalu berada dekat kaki) dan dalam penguasaan untuk dimainkan". (Arma Abdullah 1984:42) mengemukakan bahwa "menggiring bola dapat diartikan seni menggunakan beberapa bagian kaki menyentuh atau menggulingkan bola terus menerus di tanah sambil berlari". Sedangkan (Abd. Adib Rani 1992:27) mengatakan bahwa: "menggiring bola adalah istilah sepakbola untuk lari dengan bola". Berdasarkan beberapa pengertian menggiring bola yang telah dikemukakan, maka dapatlah disimpulkan bahwa menggiring bola adalah membawa bola sambil berlari dengan berbagai macam teknik sentuhan kaki dengan bola yang bertujuan untuk melewati lawan atau untuk mendapatkan posisi yang tepat guna dapat melakukan teknik gerakan selanjutnya seperti passing atau menendang bola ke gawang. Menggiring bola dalam permainan sepakbola merupakan teknik yang membutuhkan kontrol yang tepat dan koordinasi gerakan dengan tetap menjaga kelincahan agar tidak mudah terjatuh apabila diganggu oleh lawan. Menggiring bola dalam usaha untuk melewati lawan, maka perlu disertai dengan gerakan tipuan yang dapat membuat lawan bergerak tidak seimbang, misalnya melakukan gerakan ke kiri atau bahu diturunkan ke kiri kemudian dengan gerakan cepat merubah arah ke kanan setelah lawan terpedaya dengan gerak tipu yang dilakukan. Teknik menggiring bola yang disertai dengan gerak tipu untuk melewati 


\section{e-ISSN: 2657-0703 dan p-ISSN: 2085-5389}

lawan tidaklah mudah dilakukan karena membutuhkan kombinasi gerakan yang menuntut kelincahan dan ketepatan dan koordinasi gerakan yang tinggi. Menggiring bola adalah merupakan suatu upaya untuk menggerakkan bola dengan kaki sambil berlari, untuk kemudian bola diteruskan pada teman atau langsung ke gawang. Bagian kaki yang digunakan tergantung pada kondisi bola dan situasi lapangan. Teknik menggiring bola perlu dimiliki oleh setiap pemain dan sebaiknya dapat mempergunakan bagianbagian dari kedua kakinya sesuai dengan tuntutan gerakan yang dibutuhkan dalam situasi permainan agar tingkat kemampuan menggiring bola dapat tercapai secara optimal. Dengan demikian dapatlah dikatakan bahwa tanpa penguasaan teknik menggiring bola sukarlah bagi seorang pemain untuk dapat bermain dengan baik, karena teknik menggiring bola sangat berguna dalam situasi bermain. Teknik menggiring bola yang baik dapat dimiliki dan dikuasai apabila dipelajari dan dilatih dengan baik secara teratur dan sistematis serta harus didukung oleh unsur kondisi fisik yang baik pula.

Keseimbangan merupakan hal yang sangat penting pada hampir semua cabang olahraga dan merupakan dasar yang dapat menunjang penguasaan gerak keterampilan olahraga. (Kasiyo Dwijowinoto 1993:18) mengatakan bahwa: "Memelihara qualibrium yang terkendali tanpa menghabiskan berbagai tenaga internal dan eksternal yang bekerja pada tubuh merupakan suatu prasyarat dasar agar penampilan keterampilan olahraga berhasil". Keseimbangan merupakan kemampuan seseorang mempertahankan sistem tubuhnya baik dalam posisi gerak dinamis maupun dalam posisi statis. Dengan keseimbangan yang baik, maka seseorang mampu mengkoordinasikan gerakan-gerakan dan dalam beberapa ketangkasan unsur keseimbangan, seperti yang dikemukakan oleh (Harsono 1988:224) bahwa: "Keseimbangan berkontribusi dengan koordinasi diri, dan dalam beberapa keterampilan, juga dengan agilitas". Dengan demikian untuk menjaga keseimbangan dalam melakukan kegiatan jasmani, maka gerakan-gerakan yang dilakukan perlu dikoordinasikan dengan baik sebagai usaha untuk mengontrol semua gerakan. Menurut Moch. Sajoto (1988:58) tentang kemampuan menguasai letak titik berat badan yang dikenal dengan istilah keseimbangan bahwa: Keseimbangan atau balance adalah kemampuan seseorang mengendalikan organ-organ syaraf ototnya selama melakukan gerakan-gerakan yang cepat dengan perubahan letak titik berat badan yang cepat pula baik dalam keadaan statis maupun lebih-lebih dalam keadaan gerak dinamis. Kemampuan mempertahankan posisi badan dalam berbagai situasi memerlukan kemampuan tersendiri dari orang tersebut. Situasi dan kondisi keseimbangan oleh (Rahantoknam 1988:126) membagi ke dalam tiga bagian: (1) Keseimbangan statis (static balance) adalah keseimbangan mengacu pada kecakapan mempertahankan posisi badan dalam posisi diam, (2) Keseimbangan dinamis (dinamic balance) adalah keseimbangan yang memacu kepada posisi badan bergerak, dan (3) Keseimbangan rotasi (rotation balance) adalah keseimbangan yang mengacu kepada kecakapan untuk mempertahankan keseimbangan badan pada suatu sumbu dan berkontribusi dengan kecepatan untuk memperoleh kembali stimulasi yang diproduksikan oleh aparatus vertibular dalam gerakan memutar. Dari berbagai pengertian tentang keseimbangan di atas, maka dapat disimpulkan bahwa keseimbangan merupakan kemampuan seseorang mengendalikan organorgan saraf otot untuk menahan beban atau tahanan yang dilakukan dalam melakukan gerakan olahraga. Seperti pada saat menggiring bola dalam permainan sepakbola, disini dibutuhkan keseimbangan yang tinggi dalam mempertahankan titik berat badan agar tidak mudah jatuh atau goyang, sehingga seseorang mampu menggiring bola melewati lawan.

Kelincahan berkaitan erat dengan kecepatan dan kelentukan. Tanpa unsur keduanya, seseorang tidak dapat bergerak dengan lincah. Faktor keseimbangan juga sangat berpengaruh terhadap kemampuan agility seseorang. Selain itu, agility dipengaruhi oleh persepsi atlet dan kemampuan mengambil keputusan dengan cepat untuk mengubah arah. Agility berkaitan dengan gerak tubuh yang melibatkan gerak tubuh yang melibatkan gerak kaki dan perubahan-perubahan yang cepat dari posisi badan. Menurut (Mylsidayu dan Kurniawan 2015:147) mengatakan bahwa: "Agility adalah kemampuan untuk mengubah arah dan posisi tubuh dengan cepat dan tepat pada waktu sedang bergerak, tanpa kehilangan keseimbangan dan kesadaran akan posisi 


\section{Volume 10 Nomor 2, Juni 2018}

tubuhnya". Sedangkan menurut (Mylsidayu Apta, Kurniawan 2015:147) mengatakan bahwa: "Agility adalah kemampuan seseorang untuk dapat mengubah arah dengan cepat dan tepat pada waktu bergerak tanpa kehilangan keseimbangan". Menurut Halim (2011:123), mengatakan bahwa: "Kelincahan adalah kemampuan untuk mengubah posisi tubuh atau arah gerakan tubuh dengan cepat ketika sedang bergerak cepat tanpa kehilangan keseimbangan atau kesadaran orientasi terhadap posisi tubuh". Dalam komponen kelincahan ini sudah termasuk unsur mengelak dengan cepat, mengubah posisi tubuh dengan cepat, bergerak lalu berhenti dan dilanjutkan dengan bergerak secepatnya. Kemampuan seperti ini memerlukan koordinasi yang prima. Seorang atlet agar memiliki kelincahan yakni, kemampuan untuk bergerak secepatnya dari satu titik ke titik lainnya, kemudian secara tiba-tiba mengubah arah gerakannya, menghindari atau mengelilingi obyek secepatnya memerlukan kecepatan. Untuk meningkatkan komponen kelincahan ini takaran latihan tergantung tipe olahraga yang digunakan. Sedangkan menurut Lubis (2013) dalam (Mylsidayu Apta, Kurniawan 2015:148) mengatakan bahwa: "Agility adalah seperangkap kompleks yang dilakukan oleh seseorang untuk merespon stimulus eksternal dengan perlambatan, perubahan arah dan reacceleration". Kelincahan mempunyai banyak kegunaan seperti pada cabang olahraga bolabasket, pada saat melakukan menggiring bola, pemain harus cepat menghindar dari halangan lawan. Menurut (Widiatuti 2011:125) mengatakan bahwa: "Agility atau kelincahan adalah kemampuan untuk mengubah arah atau posisi tubuh dengan cepat yang dilakukan secara bersama-sama dengan gerakan lainnya". Bagi anak, kelincahan merupakan komponen kesegaran jasmani yang harus dimiliki. Tanpa kelincahan, anak dikatakan tidak dalam keadaan normal atau mungkin sedang sakit. Kelincahan bagi mereka adalah suatu yang khas sesuai dengan kodratnya. Jadi kelincahan harus menempati prioritas utama dalam melatih kesegaran jasmani setiap anak. Menurut (Noer 2002:253) mengatakan bahwa: "Kelincahan adalah kemampuan dari seseorang untuk merubah posisi dan arah secepat mungkin sesuai dengan situasi yang dihadapi dan dikehendaki". Kelincahan sangat penting fungsinya untuk meningkatkan prestasi maksimal dalam cabang olahraga. Menurut (Mylsidayu Apta, Kurniawan 2015:148), agility dapat dibagi menjadi 2 macam, antara lain sebagai berikut: (1) Agility umum adalah agility seseorang dalam melakukan olahraga pada umumnya dan menghadapi situasi hidup dengan lingkungannya, dan (2) Agility khusus adalah agility yang diperlukan sesuai dengan cabang olahraga yang diikutinya. Artinya, kelincahan yang dibutuhkan memiliki karakteristik tertentu sesuai tuntutan cabang olahraga yang ditekuninya. Jadi, kelincahan atau agility sangat penting semua cabang olahraga, terutama pada cabang olahraga yang memerlukan kelincahan. Salah satu cabang olahraga yang memerlukan kelincahan adalah sepakbola, pada saat melakukan menggiring bola, kelincahan sangat dibutuhkan karena dibutuhkan untuk menghindari lawan yang mengawal pada saat menggiring bola. Dapat disimpulkan bahwa agility adalah kemampuan mengubah arah dan cepat dan fleksibel ketika sedang bergerak. Seorang atlet atau pemain yang mempunyai agility yang baik akan mampu melakukan gerakan dengan lebih efektif dan efisien.

\section{METODE}

Adapun variabel yang ingin diteliti adalah: (1) Variabel bebas (Independent Variable) terdiri dari keseimbangan dan kelincahan, sedangkan variabel terikat (Dependent Variable) yaitu menggiring bola dalam permainan sepakbola. Desain penelitian atau rancangan penelitian yang digunakan dalam penelitian ini adalah korelasional. Populasi dalam penelitian adalah seluruh siswa SMP Negeri 33 Kepulauan Selayar yang mengikuti kegiatan ekstrakulikuler sepakbola. Sedangkan sampel yang digunakan dalam penelitian ini adalah siswa SMP Negeri 33 Kepulauan Selayar sebanyak 30 siswa dengan tehnik pengambilan sampel adalah porposive sampling. Teknik analisis data yang digunakan adalah analisis regresi tunggal dan ganda yang di analisis dengan menggunakan fasilitas komputer program SPSS versi 21.00 dengan taraf signifikan $95 \%$ atau $\alpha 0,05$.

\section{HASIL DAN PEMBAHASAN Hasil}

Hasil analisis deskriptif setiap variabel penelitian dapat dilihat dalam tabel 1 berikut: 


\section{e-ISSN: 2657-0703 dan p-ISSN: 2085-5389}

Tabel 1.

Hasil analisis deskriptif tiap variabel.

\begin{tabular}{|l|l|l|l|l|l|l|l|}
\hline Variabel & N & Sum & Mean & Stdv & Range & Min. & Max. \\
\hline Keseimbangan & 30 & 1985,00 & 66,1667 & 6,39010 & 20,00 & 55,00 & 75,00 \\
\hline Kelincahan & 30 & 383,00 & 12,7667 & 1,07265 & 4,00 & 10,00 & 14,00 \\
\hline $\begin{array}{l}\text { Kemampuan } \\
\text { menggiring bola }\end{array}$ & 30 & 332,00 & 11,0667 & 1,28475 & 4,00 & 9,00 & 13,00 \\
\hline
\end{tabular}

Untuk pengujian hipotesis tersebut maka dilakukan uji korelasi dan regresi keseimbangan, kelincahan dan kemampuan menggiring bola dalam permainan sepakbola pada siswa SMP Negeri 33 Kepulauan Selayar.

1. Ada kontribusi keseimbangan dengan kemampuan menggiring bola dalam permainan sepakbola pada siswa SMP Negeri 33 Kepulauan Selayar.

Hasil data yang diperoleh dari penelitian bertujuan untuk mengetahui antara variabel bebas dan variabel terikat serta membuktikan hipotesis yang ada. Oleh karena itu hasil pengujian hipotesis berdasarkan pengolahan data melalui analisis korelasi dan regresi dari program SPSS tentang kontribusi keseimbangan dengan kemampuan menggiring bola dalam permainan sepakbola pada siswa SMP Negeri 33 Kepulauan Selayar diperoleh sesuai rangkuman tabel 3 berikut:

Tabel 2.

Hasil analisis korelasi dan regresi untuk hipotesis pertama

\begin{tabular}{|c|l|l|l|l|l|}
\hline VARIABEL & r/R & Rs & T & Zig & $\boldsymbol{\alpha}$ \\
\cline { 1 - 4 } Keseimbangan (X1) & $-0,514$ & 0,264 & $-3,169$ & 0,000 & 0,05 \\
$\begin{array}{c}\text { Kemampuan menggiring } \\
\text { bola (Y) }\end{array}$ & & & & \\
\hline
\end{tabular}

Hipotesis statistik yang akan di uji:

$$
\begin{array}{ll}
\mathrm{H}_{0}: \beta \mathrm{x}_{1 . \mathrm{y}} & =0 \\
\mathrm{H}_{1}: \beta \mathrm{x}_{1 . \mathrm{y}} & \neq 0
\end{array}
$$

Hasil pengujian:

Berdasarkan hasil pengujian analisis korelasi dan regresi data antara keseimbangan dengan kemampuan menggiring bola dalam permainan sepakbola pada siswa SMP Negeri 33 Kepulauan Selayar. Diperoleh nilai korelasi ( $\mathrm{r}$ ) -0,514 dengan tingkat probabilitas $(0,000)<\alpha_{0,05}$, untuk nilai $\mathrm{R}$ Square (koefesien determinasi) 0,264 Hal ini berarti $26,4 \%$ kemampuan menggiring bola dalam permainan sepakbola dijelaskan oleh keseimbangan. Oleh karena probabilitas $(0,000)$ jauh lebih kecil dari $\alpha_{0,05}$, maka model regresi dapat dipakai untuk memprediksi kemampuan menggiring bola dalam permainan sepakbola (dapat diberlakukan untuk populasi dimana sampel diambil). Dari uji $\mathrm{t}$ diperoleh $-3,169$ dengan tingkat signifikan 0,000 . Oleh karena probabilitas $(0,000)$ jauh lebih kecil dari $\alpha_{0,05}$. Maka Ho ditolak dan $\mathrm{H}_{1}$ diterima atau koefesien regresi signifikan, atau keseimbangan benar-benar berkontribusi secara signifikan dengan kemampuan menggiring bola dalam permainan sepakbola. Dengan demikian dapat disimpulkan bahwa ada Kontribusi yang signifikan keseimbangan dengan kemampuan menggiring bola dalam permainan sepakbola pada siswa SMP Negeri 33 Kepulauan Selayar, sebesar $26,4 \%$. 


\section{Volume 10 Nomor 2, Juni 2018}

2. Ada kontribusi kelincahan dengan kemampuan menggiring bola dalam permainan sepakbola pada siswa SMP Negeri 33 Kepulauan Selayar.

Hasil data yang diperoleh dari penelitian bertujuan untuk mengetahui antara variabel bebas dan variabel terikat serta membuktikan hipotesis yang ada. Oleh karena itu hasil pengujian hipotesis berdasarkan pengolahan data melalui analisis korelasi dan regresi dari program SPSS tentang kontribusi kelincahan dengan kemampuan menggiring bola dalam permainan sepakbola pada siswa SMP Negeri 33 Kepulauan Selayar diperoleh sesuai dari rangkuman tabel 4 berikut:

Tabel 3

Hasil analisis korelasi dan regresi untuk hipotesis kedua

\begin{tabular}{|c|l|l|c|l|l|}
\hline VARIABEL & r/R & Rs & T & Zig & $\boldsymbol{\alpha}$ \\
\cline { 1 - 4 } Kelincahan (X2) & 0,787 & 0,620 & 6,785 & 0,000 & 0,05 \\
\cline { 1 - 3 } $\begin{array}{c}\text { Kemampuan } \\
\text { menggiring bola (Y) }\end{array}$ & & & & \\
\hline
\end{tabular}

Hipotesis statistik yang akan di uji:

$$
\begin{array}{ll}
\mathrm{H}_{0}: \beta \mathrm{x}_{2 . \mathrm{y}} & =0 \\
\mathrm{H}_{1}: \beta \mathrm{x}_{2 . \mathrm{y}} & \neq 0
\end{array}
$$

Hasil pengujian:

Berdasarkan hasil pengujian analisis korelasi dan regresi data antara kelincahan dengan kemampuan menggiring bola dalam permainan sepakbola pada siswa SMP Negeri 33 Kepulauan Selayar. Diperoleh nilai korelasi ( r ) 0,787 dengan tingkat probabilitas $(0,000)<\alpha_{0,05}$, untuk nilai $\mathrm{R}$ Square (koefesien determinasi) $0,620 \mathrm{Hal}$ ini berarti $62, \%$ kemampuan menggiring bola dalam permainan sepakbola dijelaskan oleh kelincahan .. Oleh karena probabilitas $(0,000)$ jauh lebih kecil dari $\alpha_{0,05}$, maka model regresi dapat dipakai untuk memprediksi kemampuan menggiring bola dalam permainan sepakbola (dapat diberlakukan untuk populasi dimana sampel diambil). Dari uji $\mathrm{t}$ diperoleh 6,785 dengan tingkat signifikan 0,000 . Oleh karena probabilitas $(0,000)$ jauh lebih kecil dari $\alpha_{0,05}$. Maka Ho ditolak dan $\mathrm{H}_{1}$ diterima atau koefesien regresi signifikan, atau kelincahan benar-benar berkontribusi secara signifikan dengan kemampuan menggiring bola dalam permainan sepakbola. Dengan demikian dapat disimpulkan bahwa ada kontribusi yang signifikan kelincahan dengan kemampuan menggiring bola dalam permainan sepakbola pada siswa SMP Negeri 33 Kepulauan Selayar, nilai sebesar $62,0 \%$

3. Ada kontribusi keseimbangan dan kelincahan dengan kemampuan menggiring bola dalam permainan sepakbola pada siswa SMP Negeri 33 Kepulauan Selayar.

Hasil data yang diperoleh dari penelitian bertujuan untuk mengetahui antara variabel bebas dan variabel terikat serta membuktikan hipotesis yang ada. Oleh karena itu hasil pengujian hipotesis berdasarkan pengolahan data melalui analisis regresi dari program SPSS tentang kontribusi antara keseimbangan dan kelincahan dengan kemampuan menggiring bola dalam permainan sepakbola pada siswa SMP Negeri 33 Kepulauan Selayar diperoleh sesuai dari rangkuman tabel 5 berikut: 
e-ISSN: 2657-0703 dan p-ISSN: 2085-5389

Tabel 4.

Hasil analisis regresi untuk hipotesis ketiga

\begin{tabular}{|c|c|c|c|c|c|}
\hline VARIABEL & r/R & Rs & T & Zig & $\boldsymbol{\alpha}$ \\
\hline $\begin{array}{c}\text { Keseimbangan (X1), dan } \\
\text { kelincahan (X2) }\end{array}$ & 0,788 & 0,620 & 22.042 & 5.032 & 0,000 \\
$\begin{array}{c}\text { Kemampuan menggiring } \\
\text { bola(Y) }\end{array}$ & & & & \\
\hline
\end{tabular}

Hipotesis statistik yang akan di uji:

$\mathrm{H}_{0}: \mathrm{Rx}_{1.2 . \mathrm{y}}=0$

$\mathrm{H}_{1}: \mathrm{Rx}_{1.2 . \mathrm{y}} \neq 0$

Hasil pengujian:

Berdasarkan hasil pengujian analisis regresi data antara keseimbangan dan kelincahan dengan Kemampuan menggiring bola dalam permainan sepakbola pada siswa SMP Negeri 33 Kepulauan Selayar. Diperoleh nilai regresi ( $\mathrm{R}$ ) 0,788 dengan tingkat probabilitas $(0,000)<\alpha_{0,05}$, untuk nilai $R$ Square (koefesien determinasi) 0,620. Hal ini berarti $62 \%$ kemampuan menggiring bola dalam permainan sepakbola dijelaskan oleh keseimbangan dan kelincahan . Dari uji Anova atau F test, didapat $\mathrm{F}$ hitung adalah 22,042 dengan tingkat signifikansi 0,000 . Oleh karena probabilitas $(0,000)$ jauh lebih kecil dari $\alpha_{0,05}$, maka model regresi dapat dipakai untuk memprediksi kemampuan menggiring bola dalam permainan sepakbola (dapat diberlakukan untuk populasi dimana sampel diambil). Dari uji $\mathrm{t}$ diperoleh 5,032 dengan tingkat signifikan 0,000 . Oleh karena probabilitas $(0,000)$ jauh lebih kecil dari $\alpha_{0,05}$. Maka Ho ditolak dan $\mathrm{H}_{1}$ diterima atau koefesien regresi signifikan, atau keseimbangan dan kelincahan benar-benar berkontribusi secara signifikan dengan kemampuan menggiring bola dalam permainan sepakbola. Dengan demikian dapat disimpulkan bahwa ada kontribusi yang signifikan keseimbangan dan kelincahan dengan kemampuan menggiring bola dalam permainan sepakbola pada siswa SMP Negeri 33 Kepulauan Selayar, nilai sebesar $62,0 \%$

\section{Pembahasan}

1. Ada kontribusi keseimbangan dengan kemampuan menggiring bola dalam permainan sepakbola pada siswa SMP Negeri 33 Kepulauan Selayar.

Hasil analisis statistik menunjukkan bahwa ada kontribusi keseimbangan terhadap kemampuan menggiring bola dalam permainan sepakbola pada siswa SMP Negeri 33 Kepulauan Selayar. Apabila hasil penelitian ini dikaitkan dengan teori dan kerangka pikir yang mendasarinya, maka pada dasarnya hasil penelitian ini mendukung dan memperkuat teori dan hasil-hasil penelitian terdahulu yang sudah ada. Ini membuktikan bahwa keseimbangan sangat mempengaruhi kemampuan menggiring bola dalam permainan sepakbola. keseimbangan adalah merupakan kemampuan seseorang mengendalikan organ-organ saraf otot untuk menahan beban atau tahanan yang dilakukan dalam melakukan gerakan olahraga. Seperti pada saat menggiring bola dalam permainan sepakbola, disini dibutuhkan keseimbangan yang tinggi dalam mempertahankan titik berat badan agar tidak mudah jatuh atau goyang, sehingga seseorang mampu menggiring bola melewati lawan. Jadi, keseimbangan sangat menunjang kemampuan menggiring bola dalam permainan sepakbola. Dengan demikian keseimbangan memiliki Kontribusi yang signifikan terhadap kemampuan menggiring bola dalam permainan sepakbola pada siswa SMP Negeri 33 Kepulauan Selayar. 
2. Ada kontribusi kelincahan dengan kemampuan menggiring bola dalam permainan sepakbola pada siswa SMP Negeri 33 Kepulauan Selayar.

Hasil analisis statistik menunjukkan bahwa ada kontribusi yang sigifikan kelincahan terhadap kemampuan menggiring bola dalam permainan sepakbola pada siswa SMP Negeri 33 Kepulauan Selayar. Apabila hasil penelitian ini dikaitkan dengan teori dan kerangka pikir yang mendasarinya, maka dalam dasarnya hasil penelitian mendukung dan memperkuat teori dan hasil-hasil penelitian terdahulu yang sudah ada. Ini membuktikan bahwa kelincahan sangat mempengaruhi kemampuan maksimal dalam pencapaian passing bola. Kelincahan adalah kemampuan mengubah arah dan cepat dan fleksibel ketika sedang bergerak. Seorang atlet atau pemain yang mempunyai agility yang baik akan mampu melakukan gerakan dengan lebih efektif dan efisien. kelincahan memiliki peran yang penting demi tercapainya kemampuan penampilan secara baik, seorang atlet sangat perlu untuk memiliki, memelihara dan menjaganya agar kemampuan agility tetap menjadi satu kesatuan dengan kemampuan fisik yang lainnya pada saat melakukan menggiring bola, kelincahan sangat dibutuhkan karena dibutuhkan untuk menghindari lawan yang mengawal pada saat menggiring bola, Dengan demikian kelincahan memiliki kontribusi terhadap kemampuan menggiring bola dalam permainan sepakbola pada siswa SMP Negeri 33 Kepulauan Selayar.

3. Ada kontribusi keseimbangan dan kelincahan dengan kemampuan menggiring bola dalam permainan sepakbola pada siswa SMP Negeri 33 Kepulauan Selayar.

Hasil analisis statistik menunjukkan bahwa ada kontribusi yang signifikan keseimbangan dan kelincahan terhadap kemampuan menggiring bola dalam permainan sepakbola pada siswa SMP Negeri 33 Kepulauan Selayar. Apabila hasil penelitian ini dikaitkan dengan teori dan kerangka pikir yang mendasarinya, pada dasarnya hasil penelitian ini mendukung dan memperkuat teori yang sudah ada. Ini membuktikan bahwa keseimbangan dan kelincahan sangat mempengaruhi kemampuan menggiring bola dalam permainan sepakbola. Untuk layaknya seorang pemain sepakbola perlu ditunjang dengan kemampuan fisik keseimbangan dan kelincahan, maka hasil yang diperoleh akan lebih maksimal dalam melakukan passing bola. Sudah di bahas di atas bahwa dalam melakukan menggiring bola yang sempurna perlu di tunjang keseimbangan. menggiring bola dalam permainan sepakbola. Keseimbangan adalah merupakan kemampuan seseorang mengendalikan organ-organ saraf otot untuk menahan beban atau tahanan yang dilakukan dalam melakukan gerakan olahraga Hasil yang maksimal apabila menguasai kelincahan yang baik. Keseimbangan berfungsi untuk menjaga posisi badan agar tetap seimbang pada saat melakukan menggiring bola. kelincahan berfungsi untuk mempermudah melewati pemain lawan sehingga lawan sulit merebut bola pada pemain yang mempunyai kelincahan yang baik. Jadi, keseimbangan dan kelincahan sangat berkontribusi dalam melaksanakan menggiring bola dalam permainan sepakbola. Akan tetapi bukan hanya dua faktor yang dapat menunjang dalam kemampuan menggiring bola dalam permainan sepakbola. Dengan demikian keseimbangan dan kelincahan memiliki kontribusi terhadap kemampuan menggiring bola dalam permainan sepakbola pada siswa SMP Negeri 33 Kepulauan Selayar.

\section{SIMPULAN DAN SARAN}

Berdasarkan hasil penelitian dan pembahasan yang telah dikemukakan, maka dapat ditarik sebuah kesimpulan sebagai berikut:

1. Keseimbangan memiliki kontribusi dengan kemampuan menggiring bola dalam permainan sepakbola pada siswa SMP Negeri 33 Kepulauan Selayar sebesar $26,4 \%$. 


\section{e-ISSN: 2657-0703 dan p-ISSN: 2085-5389}

2. Kelincahan memiliki kontribusi dengan kemampuan menggiring bola dalam permainan sepakbola siswa SMP Negeri 33 Kepulauan Selayar sebesar $62 \%$.

3. Keseimbangan dan kelincahan memilki kontribusi dengan kemampuan menggiring bola dalam permainan sepakbola siswa SMP Negeri 33 Kepulauan Selayar sebesar 62\%.

Berdasarkan kesimpulan penelitian tersebut di atas, maka dapat disarankan sebagai berikut :

1. Dapat dijadikan pertimbangan untuk memilih atlet sepekbola di SMP Negeri 33 Kepulauan Selayar, dengan mengacu pada hasil penelitian tersebut.

2. Guru olahraga, agar didalam memilih teknik permainan sepakbola yang ingin dikembangkan perlu memperhatikan komponen fisik yang dimiliki seperti keseimbangan dan kelincahan.

3. Diharpkan siswa dapat meningkatkan keterampilan bermain sepakbola dengan cara mengikuti kegiatan ekstrakurikuler di sekolah, atau mengikuti sekolah sepakbola di daerah masing-masing.

\section{DAFTAR RUJUKAN}

Abdullah, Arma. 1984. Olahraga Untuk Perguruan Tinggi. Sastra Udayana, Jakarta.

Abdullah Ma'ruf. 2015. Metodologi Penelitian Kuantitatif. Yogyakarta: Aswaja Pressindo

Aip Syarifuddin dan Muhadi. 1992. Pendidikan Jasmani dan Kesehatan. Jakarta: Depdikbud.

B.Edward Rahantoknam. 1988. Belajar Motorik: Teori dan Aplikasi Dalam Pendidikan Jasmani dan Olahraga. Jakarta: Depdikbud.

Batty, Eric C. 2007. Latihan Metode Baru Sepakbola Serangan. Bandung: Pionir Jaya

Darmadi, Hamid. 2013. Metode Penelitian Pendidikan dan Sosial. Bandung: Alfabeta

Dwijowinoto, Kasiyo. 1993. Dasar-dasar Ilmiah Kepelatihan. IKIP : Semarang Press

Haddade, Ilyas \& Tola, Ismail. 1991. Penuntun Mengajar Dan Melatih Sepakbola. FOK IKIP Ujung Pandang.
Hamidsyah Noer, dkk. 2002. Kepelatihan Dasar. Jakarta: Pusat Penerbitan Universitas Terbuka.

Harsono. 1988. Coaching dan Aspek-aspek Psikologi dalam Coaching. Jakarta : Penerbit Departemen Pendidikan dan kebudayaan Proyek Pengembangan Pendidikan Tinggi.

Ismaryati, 2008. Tes dan pengukuran olaragah . Solo: Penerbit lembaga pengembangan pendidikan (LPP) dan UPT penetbitan dan percetakan UNS (UNS Press) Universitas sebelas maret surakarta

Lukman,Yudianto. 2009. Teknik Bermain Sepak Bola dan Futsal. Bandung: Visi 7.

Mylsidayu Apta, Kurniawan Febi. 2015. Ilmu Kepelatihan Dasar. Bandung: Alfababeta.

Ngatiyono. 2008. Pendidikan dan jasmani dan kesehatan 1 . Solo PT.Tiga Serangkai Mandiri

Nur Ichsan Halim. 2011. Tes dan Pengukuran Kesegaran Jasmani. Makassar: Badan Penerbit UNM.

Nurhasan. 2000. Tes dan Pengukuran Pendidikan Olahraga. Bandung: FPOK UPI

Rani, Abd. Adib. 1992. Materi dan evaluasi mengajar permainan sepakbola. Ujung Pandang : FPOK IKIP.

Saharyullah 2018. Sejarah Peraturan dan Pedoman melatih. Makassar : Badan Penerbit Universitas Negeri Maakassar.

Sajoto, Moch. 1988. Pembinaan kondisi fisik dalam olahraga. Jakarta: Departemen Pendidikan dan Kebudayaan Dirjen Dikti.

Sudaryono, Gaguk Margono, Wardani Rahayu. 2013. Pengembangan Instrumen Penelitian Pendidikan. Jakarta: Graha Ilmu.

Sugiyono. 2015. Metode Penelitian Pendidikan. Jakarta: Alfabeta

Surakhmad, Winarno. 2004. Pengantar Penelitian Ilmiah, Dasar, Metode, Teknik. Bandung: Tarsito.

Widiastuti. 2011. Tes dan Pengukuran Olahraga. Jakarta : PT. Bumi Timur Jaya. 